\title{
Censorship Towards the Subject of the Warsaw Uprising in Belles-Lettres in 1956-1958
}

Censorship, like propaganda, constituted one of the key instruments of the communist regime in the People's Republic of Poland (PRL). Through control and influence the regime shaped literature and ensured that the presented image did not diverge from the applicable "Party policy". Particular attention was placed on political content which, by definition, could undermine the system in place. The "political" category was understood very broadly. The authorities saw the possibility of danger not only in texts describing contemporary problems but also in literature discussing the theme of WWII, a sensitive area for the Party considering the USSR's engagement in the seizure of rule, against the will of the legal Polish government in London and much of Polish society. In those circumstances the absolutely positive image of WWII that the People's Republic promoted by the authorities clashed with the actual course of events, which many people still remembered. In that situation, the task of censorship was to support the official propaganda through manipulating facts, carefully monitoring all content, eliminating inconvenient texts, adding large fragments and thus, influencing people's state of awareness.

This topic also includes the approach of censorship towards the problem of the Warsaw Uprising, which in 1956-1958 received numerous studies in period literature. The main characteristic of that period, regardless of its name (in literary studies it is referred to as the "thaw" 2 while in historiography it is also referred to as the "October turning point"3), was the political turning point which

\footnotetext{
* Mgr, e-mail: agnieszka_kloc@wp.pl, Maria Curie-Skłodowska University in Lublin, Institute of History, 20-031 Lublin, pl. M. Curie-Skłodowskiej 4a.

${ }^{1}$ The article was written as part of the National Program for the Development of Humanities: "Censorship towards Polish literature in 1945-1989".

${ }^{2}$ Vide Słownik realizmu socjalistycznego, Z. Lapiński, W. Tomasik (eds.), Cracow, 2004, pp. 163-167.

${ }^{3}$ Vide Polska 1956: próba nowego spojrzenia. Materiały sesji naukowej zorganizowanej przez Instytut Historii PAN, Polskie Towarzystwo Historyczne i Instytut Studiów Politycznych PAN w Warszawie w dn. 21-22 października 1996 r., K. Kersten (ed.), Series: "Polska 1944/45-1989. Studia i materiały", vol. 3, Poznań 1997.
} 
resulted in a liberalisation of cultural activities, though it did not introduce a total freedom of speech. Censorship continued, though, as in the case of other institutions, it limited the scope of its repressions in comparison to the Stalinist period.

For this discussion explication of the activities of censorship towards the specified topic, I focus mainly on poetry and prose of 1956-1958. My analysis considers the so-called "depth" of censorship interventions. In the first group, I included texts which received approval without implementing any changes or with minor interventions which did not alter their interpretations. The second category covers literary works altered considerably through the elimination of fragments which had been deemed inconvenient or politically dangerous (negative censorship) and texts which had been altered by adding passages written by the censors (positive censorship), which modified the general meaning of the text. The third group includes halted and unpublished items. Within these classifications I particularly focused not only on the methods of exerting influence and the scope of content approved by the Main Office of Control of Press, Publications and Shows, but also on the attitude of the authors, who often participated in the described events. This analysis reveals the direct influence censors had on the shape of published literature and the related promotion of "appropriate" standards of writing. Those formed because of the confrontation of censors assumptions and the submitted texts, which constituted an expression of the worldview and output of a given author. Additionally, texts which had been subjected to interventions offered the authors perceptible "parameters", which identified the limits of freedom of speech.

Since the outbreak of the Uprising in Warsaw on 1 August 1944, facts were manipulated. This lasted until 1947-1948, when the topic of the Warsaw Uprising was subdued altogether ${ }^{4}$. The first evaluation of the Uprising was presented in a brochure entitled: Powstanie $w$ Warszawie - fakty i dokumenty [Uprising in Warsaw. Facts and documents], issued on 18 October 1944 by the Propaganda Division of the Chief Political and Education Management of the Polish Armed Forces. Its contents, in line with propaganda guidelines, imposed the one proper evaluation of the actions of the Home Army, labelling them as a "criminal political game" and, subsequently, highlighting the achievements of the Polish Workers' Party (PPR) underground. In the early 1945, there appeared the "Giant and the disgusting reactionary dwarf" poster by Włodziemierz Zakrzewski, antagonising the population against the Home Army, and on 21 July 1945 a speech delivered by Gomułka completed the previously outlined representation. At the beginning, he recognised the bravery of the people of Warsaw and at the same

${ }^{4}$ Even though many readers were aware of the administrative ban on raising the topic of the Warsaw Uprising, censorship in 1957 still kept the facts of how for many years the discussed issue in belles-lettres had been concealed from dissipating into general knowledge. Vide AAN, GUKPPiW, ref. no. 497 (39/3), 1. 52. 
time emphasised the pointless sacrifice of the thousands of victims. He went on to cite the goals which the Home Army leadership were supposed to be following when commencing the Uprising: to reintroduce the Sanation order, to ignite a civil war to overthrow the Polish Committee of National Liberation (PKWN), to aggravate the Polish-Soviet relations, to disrupt the unity of the allied nations and to conduct an international charade to discredit the "democratic forces" by using the failure of the Uprising 5 .

For the analysis of the discussed topic a breakthrough moment was the death of Stalin and the speech delivered three years later by Nikita Khrushchev which constituted a secret report revealing Stalinist crimes, which in turn resulted in the rise of reform-makers and propagators of tempering the censorship policy. The breakthrough in Poland was the $3^{\text {rd }}$ Plenary Session of the Central Committee of the Polish United Workers' Union (KC PZPR). The authorities condemned doctrine-based policies and the "totalitarian" methods of influencing creators. The mere fact of shaping their vision through free discussion was supposed to be an expression of progress in the state authorities relations with artists ${ }^{6}$.

Changes also applied to the national security forces. Beginning in 1955, political prisoners were starting to be released from incarceration. The debate inside the Party began to include the problem of abuses and infringements of law and order and the need for exoneration. From that reality came the famous article by Jerzy Ambroziewicz, Walery Namiotkiewicz and Jan Olszewski published in Po prostu. They indicated the problem of the unfair evaluation of the Home Army members who returned to life within the society. The ensuing debate regarding former Home Army soldiers revived the memory of the organisation, particularly in the context of the Warsaw Uprising?

It should also be stressed that in terms of literature the authors' departure from the Socialist realist standards and Stalinist rules occurred in a rather chaotic manner. It was more of a rambling than following a specific direction, associated with the ongoing unfocussed processes of change. Artists, often at a loss, tried to seek the limits of creative freedom and the scope of freedom of speech on their own ${ }^{8}$.

The officially "revived" memory of the events in Warsaw resulted in the emergence of commentaries and literary works raising the topic.

5 J.Z. Sawicki, Bitwa o prawdę. Historia zmagań o pamięć Powstania Warszawskiego. 1944-1989, Poznań 2005, pp. 19-37.

${ }^{6}$ B. Fijałkowska, Polityka i twórcy 1948-1959, Poznań 1985, p. 288.

${ }^{7}$ J.Z. Sawicki, op. cit., pp. 100-103.

${ }^{8}$ J. Galant. Odmiany wolności. Publicystyka, krytyka i literatura polskiego Października, Poznań 2010, p. 26. 


\section{Poetry}

Even in early 1956, GUKPPiW received a collection of poems by Zbigniew Herbert ${ }^{9}$ (Chord of Light), which were approved for print in their entirety. In a laconic and generalist review of 5 April the reviewer concluded: "Herbert's poetry is dominated by lyrical associations - subtlety, play of light (he himself points that out in the title), regardless of the standard of the poem. That can be a wartime recollection, own home or family, Greek mythology or the veneration for the dead"10. The awkward statement included in the review proved the officer's helplessness towards Herbert's poetics ${ }^{11}$. The censor did not even attempt a deeper interpretation, though literary critics did soon after the collection was published, finding in such poems as: On Troy, Red Cloud or Warsaw Cemetery elements of patriotism and an "attachment to the history of the nation and the price one pays for attachment" ${ }^{\prime 2}$. The Uprising also echoed in other texts in the collection, for example a fragment of Three Poems By Heart drew an image of the tragedy of Warsaw:

Żony w letnie wieczory

cierpliwie czekały na usta

pachnące znajomym tytoniem

Kobiety nie mogły dzieciom

odpowiedzieć: czy wróci

Gdy zachodziło miasto

gasiły ogień rękami

przytkniętymi do oczu

Dzieci z naszej ulicy

śmierć miały bardzo ciężką

[...] in the summer nights wives patiently waited for mouths

smelling of familiar tobacco

women couldn't answer their kids: he'll be back when the city went down they put out fires hands pressed up to their eyes

the children from our street met with a very hard death [...]

${ }^{9}$ During the WWII occupation, Zbigniew Herbert was affiliated with the underground - apart from studies at the secret John Casimir University in Lviv he was a member of the Home Army. In 1944, before the invasion of the Red Army, he moved to Proszowice near Krakow and lived there until January 1945. He did not participate directly in the Warsaw Uprising. Vide A. Hejman, Herbert Zbigniew, in: Współcześni polscy pisarze i badacze literatury. Słownik biobibliograficzny, J. Czachowska, A. Szałagan (eds.), vol. 3, Poznań 1994, pp. 230-231.

${ }^{10}$ As cited in: K. Budrowska, Literatura i pisarze wobec cenzury PRL 1948-1958, Białystok 2009, p. 57.

${ }^{11}$ Ibidem.

${ }^{12}$ K. Wyka, Składniki świetlanej struny, “Życie Literackie” 14 Oct 1956, issue 247, p. 3. 
Ptaki dzieci i żony nie mogą mieszkać w żałobnych skorupach miasta w ostygłych puchach popiołów

Miasto stoi nad wodą gładką jak pamięć lustra odbija się w wodzie od dna birds children and wives cannot dwell in the city's pitiful shell in the cool down of ash the city which stands on water smooth as a mirror's memory is reflected from the river-bed ${ }^{13}$

It seems that the officer's lack of insight was, in that case, fairly justified. Following the censors's train of thought: many poems had already been published, thus, the fact that they had been verified by the Voivodship Control Bureau for Press meant for the GUKPPiW officer it was only a formality to issue a positive censorship evaluation without any in-depth study of the contents ${ }^{13}$.

Additionally, the fact that the approval applied to a small number of copies $(1205)^{14}$ suggested not only that it was assumed that there would not be a large interest in Herbert's poetry among readers, but more to the point as a form of precaution in the evolving situation of literature ${ }^{15}$. The authorities manipulated the circulation: a small number of copies reached a small readership, thus any possible ambiguous Aesopian expressions ${ }^{16}$ would not find a broader group of readers.

The Uprising was also echoed in a poem by Tadeusz Kubiak ${ }^{17}$ entitled Pieśń o drzewie cynamonowym [Song Of The Cinnamon Tree] from the Pierścienie [Rings] collection. Per the dating of the censor's review, the poetic collection was released to the censorship officer Trębicki on 17 February 1956. A five-day analysis of 44 poems enabled the censor to formulate the main conclusions:

${ }^{13}$ Z. Herbert, Chord of Light, Poznań 1956, pp. 11-12.

${ }^{14}$ The proposed number of copies was defined by the publishing house in the form of a short application for granting the permit for publishing a given book. Usually institutions approved the proposed number of copies, however, in the case of controversial works, the number was modified.

${ }^{15}$ Already by the end of 1955 there appeared voices in the journals "Nowa Kultura" and "Życie Literackie" on the new focus in poetry fulfilled by young writers, such as Herbert. When compared to A Poem For Adults by Adam Ważyk published in mid-year, which was evaluated unequivocally negatively by Jakub Berman and Edward Ochab, Herbert's poetry was not considered as political destructive. Vide T. Mielczarek, Pisarze w PRL "pieszczochy władzy" czy ofiary systemu, in: Niewygodne dla władzy. Ograniczenie wolności słowa na ziemiach polskich w XIX i XX wieku, D. Degen, J. Gzella (eds.), Toruń 2010, pp. 219-220.

${ }^{16}$ Even the title of the poem: Red Cloud and the words: "A red cloud of dust / summoned that fire- / the setting of a city / over earth's horizon" could be interpreted in two ways: as having an exceptionally (as for Herbert's poetics) literal meaning: the image of rising dust of redbrick buildings being destroyed or the image of burning Poznań, but also the "red" could evoke associations with the Soviet army, particularly in the case of a former member of the Home Army.

17 Tadeusz Kubiak probably did not participate in the Warsaw Uprising, but he did participate in the underground efforts (member of the Union of Armed Struggle (ZWZ) and the Home Army). In 1943, he established an underground journal "Jutro Poezji", where he made his début. Vide A. Szałagan, Kubiak Tadeusz, in: Współcześni polscy pisarze..., vol. 4, Warsaw 1996, p. 429. 
Similarly to Różewicz, though using less bold means, mixing blank verse with classic form, Kubiak in the poetry collection encloses the essence of occupation experiences (e.g. the pain of a mother after losing her son), the tragedies of wartime past (Zegar ratuszowy w pewnym miasteczku [City Hall Clock In A Certain Town]), he once more gives strong poems with contemporary themes, such as a response to the events in Guatemala - O drzewie cynamonowym [On The Cinnamon Tree], etc. ${ }^{18}$

In the above-mentioned poem, the censor identified only the description of contemporary events, though it also offered a summary of certain associations: riots in Guatemala ${ }^{19}$ with the wartime destruction in Poland including the tragedy of Warsaw in 1944. The lyrical subject presented the following situation:

Widziałem domy opustoszałe

okna rozwarte na przestrzał.

Tych okien nikt nigdy nie zamykał

ani wśród burzy, ani wśród deszczu

wśród gradobicia, wśród mrozu i śniegu.

[...]

Znam domy mojej ojczyzny. To nie były

domy miłości ani rozkoszy,

ani starości, ani modlitwy.

$[\ldots]$

Ach, ludzie. Których nie było udziałem

wychodzić z miasta pod milczenie gwiazd,

w obojętności wojennego nieba

dzielić się chlebem zeschłym na kamień, [...]
I saw houses deserted

windows opened wide.

Those windows no one never closed

neither in storm, nor rain

in hail, cold or snow.

[...]

I know the homes of my motherland.

Those were not

homes of love or pleasure,

or old age, or prayers.

[...]

Oh, people. Who did not

exit the city under the silence of the stars, in the indifference of the wartime sky

to share stone-dry bread,

$[\ldots]^{20}$

The censor did not notice the reference made by a former member of ZWZ and later the Home Army to the moment when the partisans were leaving Warsaw on the "indifference of the wartime sky" - lack of help from any side. Additionally, the censor's exceptionally positive attitude towards Kubiak's works was associated with his glorifying-communist output devoted to Bierut ${ }^{21}$.

The number of copies, as in the case of Herbert, was not large and amounted

\footnotetext{
18 AAN, GUKPPiW, ref. no. 424 (31/36), 1. 82.

${ }^{19}$ In 1954 in Guatemala, there was a coup d'état, as a result of which the military removed the ruling left-wingers from power; it was accompanied by public disorders.

${ }^{20}$ T. Kubiak, Pierścienie, Poznań 1956, pp. 59-60.

${ }^{21}$ M. Głowiński, Rytuat i demagogia. Trzynaście szkiców o sztuce zdegradowanej, Poznań 1992, pp. 110-111.
} 
to 2705 copies. The decision to publish it without any interventions might have been influenced by the fact that some of the poems had previously been printed in journals, thus having been verified, probably by the Voivodship Control Bureau for Press: "Generally, the collection, which includes poems previously published in literary journals as well as in, e.g. the most recent issue of Twórczość, makes a quite pleasant impression. Poetry"22.

A collection of poems by Jerzy Ficowski ${ }^{23}$, a former Warsaw Uprising partisan, belongs to a group of poetic works raising the topic of the fights in Warsaw and which were subjected to extensive deletions. The collection entitled Moje strony świata [My Cardinal Points] underwent verification in 1957. The preserved sheets of the collection bear two-colour corrections, which shows how controversial some of the works were. The initial interventions made finely in pencil were limited to notes only, e.g. "Ż.L. 21 VII 57", indicating the name and issue of a journal where a given poem was published (in this case it was "Życie Literackie" of 21 July 1957) and some minor underscores of single words or expressions. The censor had the most problems with a poem with the trivial title of Plwocina $[\text { Sputum }]^{24}$, which described the situation immediately after the Warsaw Uprising when the lyrical subject "gives up" fighting and, at the same time, is faced with the new reality and the slogan coined by communists during the Uprising: "Home

${ }^{22}$ AAN, GUKPPiW, ref. no. 424 (31/6), 1. 83.

${ }^{23}$ J. Ficowski joined the Home Army before 1943. At the age of 20 he took part in the Warsaw Uprising. He fought in Mokotów and was captured by the Nazi army. In 1945, he returned to Poland and participated in the state literary life. He was also among the poets who wrote commissioned poems. Vide E. Głębicka, Ficowski Jerzy, in: Wspótcześni polscy pisarze..., vol. 2, Poznań 1991, p. 291.

${ }^{24}$ The poem was removed from the collection, which is why it is worth quoting its key fragments:

Szliśmy dwaj, porzuciwszy kolczaste widnokręgi.

Zawołali nam witający, co im ślina na język przyniosła:

- AK - zapluty karzeł!

- Zaplute karły akowskie!

I do ciężkich cieni nas zaprzęgli, abyśmy wlekli je za sobą, po własnej, chętnej grobami ziemi, kazali karleć

i pluli, pluli niestrudzeni, na żywe i na umarłe.

Jeden z nas się pośliznął

na ich plwocinie

i padł pod drzewem

Czerwonego Boru -

na zawsze osiemnastoletni. [...]
Two of us walked, having left the barbed horizons.

Those who saw us cried, what first came to their minds:

- Home Army - disgusting dwarf!

- Disgusting Home Army dwarfs!

And they harnessed us to heavy shadows, so that we could drag them behind us, over our own, hungry for graves earth, made us dwarf and spat, spat tirelessly, on what was alive and dead alike.

One of us slipped on their sputum and fell under a tree of the Red Wood eighteen forever. [...]

As cited in: AAN, GUKPPiW, ref. no. 426 (34/2), 1. 20. 
Army, the disgusting reactionary dwarf". The officer decided to change the title to Kolczaste widnokregi [Barbed Horizons]. He introduced the next correction using a red pencil crossing out twice the title Plwocina and correcting the previous suggestion written in pencil ${ }^{25}$. Eventually, the entire poem was crossed out with two red lines (one thin and another thick), which indicate some discussion and that the decision was made by more than one censor. Unfortunately, no post-intervention review survived, so one can only suspect the reasons for removing the poem. First, the "Home Army, the disgusting reactionary dwarf" slogan was no longer promoted in the discussed period ${ }^{26}$. That was a result of the publication in Po prostu in March 1956 of an article by Jerzy Ambroziewicz, Walery Namiotkiewicz and Jan Olszewski entitled Na spotkanie ludziom z AK [Meeting the people from the Home Army $]^{27}$, which the authors began by identifying the offensive posters and slogan which constituted a form of repression. Therefore, during the announced exoneration of the Home Army, the mentioned slogan, magnified in the poem through the use of irony, became politically unfavourable as it exposed the hostile activities of communists. Second was the depiction of the death of a member of the Home Army at the Czerwony Bór forest, seemingly too clear in its Aesopian nature [czerwony $=$ red] and thus negatively affecting Polish-Soviet relations. Finally, the poem as a whole might had been received as an excessively aggressive attack against the contemporary system. The fact that it had been published in Życie Literackie under the original title and content was irrelevant ${ }^{28}$.

No changes were introduced to the other poem entitled Dogasanie [Fading $]^{29}$. The lyrical subject recalls his friends and brothers in arms who had fallen in the Uprising. At the same time, he emphasised the fact that the tragedy was passed over in silence for many years, that it was forbidden to hold any anniversary celebrations or care for cemeteries and he accused the authorities of manipulating the memory about the fallen. Regardless of such passages as:

$[\ldots]$ Tylko goją się rany,
tak na cmentarzach
rośnie las.

P.S.

Chwila milczenia cieniom,

\begin{abstract}
[...] Only wounds are healing, thus in cemeteries a forest grows.
\end{abstract}

P.S.

A moment of silence to the shadows,

${ }^{25}$ The style of handwriting suggests the notes were made by one censor using two colours of pencil.

${ }^{26}$ Z. Romek, Cenzura a nauka historyczna w Polsce, 1944-1970, Poznań 2010, p. 277.

${ }^{27}$ J. Ambroziewicz, W. Namiotkiewicz, J. Olszewski. Na spotkanie ludziom z AK, "Po prostu" 1956, issue 11, p. 7.

${ }^{28}$ The only difference between the version of the poem that was sent to GUKPPiW and the one published in Życie Literackie was the lack of a space between lines 23 and 24, which had no influence on its general message. Vide Życie Literackie, 24 Feb 1957, issue 8 (266), p. 5.

${ }^{29}$ AAN, GUKPPiW, ref. no. 426 (34/2), 1. 36. 
a z chwil tych - całe lata milczące, $\mathrm{z}$ tych cieni - chmura nad ziemią.

[...] Nie myjcie nimi brudnych rąk, łzy muszą zostać czyste. [...] and from those moments - whole years of silence, from those shadows - a cloud over the earth.

[...] Do not wash your dirty hands with them, tears must remain pure. $[\ldots]^{30}$

the poem was approved in its entirety ${ }^{30}$.

Eventually, five poems were removed from the collection ${ }^{31}$, including one which raised the topic of the Uprising and at least three unrelated to the topic but which had been published in Życie Literackie.

In early 1958, GUKPPiW received from the Ministry of National Defence Śpiewnik zastępowy [Unit Songbook] developed by Elżbieta Dziębowska and Jerzy Dargiel. It was developed for the Polish Scouting and Guiding Association (ZHP).

During the Warsaw Uprising the ZHP consisted of various organisations, including the Gray Ranks, the battalions of which operated jointly with the Home Army HQ and the Government Delegation for Poland fulfilling a special role in the fights ${ }^{32}$ and later in maintaining the memory of the events of $1944^{33}$. When verifying the Śpiewnik, censorship did not attempt to question the traditions of the Gray Ranks or their engagement in the Uprising. The best known songs, i.e. Marsz Mokotowa [Mokotów March] and Pałacyk Michla [Michler's Palace] (with endnotes regarding their authors and specifying where the songs were sang), which were created during the fights for Warsaw, did not raise any reservations, though the censor in the review dated 25 April did stress their Home Army origins $\mathrm{s}^{34}$. The large number of copies $(30,000)$ indicated that singing about "boys from Parasol" and their brave leaders who "march in the front line risking their heads" 35 or about Mokotów fighting on its own in burning Warsaw ${ }^{36}$ did not cause any objections on the part of the GUKPPiW. However, the images of ruins with the "anchor" included in Śpiewnik proved unprintable ${ }^{37}$. That could

\footnotetext{
${ }^{30}$ Ibidem, 1. 37.

${ }^{31}$ Ibidem, ref. no. 591 (60/2), 1. 1.

${ }^{32}$ Vide Z. Głuszek „Victor”, Zawsze na pierwszej linii. Harcerstwo w Powstaniu, in: Powstanie warszawskie 1 sierpnia - 2 października. Stużby w walce, R. Śreniawa-Szypiowski (ed.), Poznań 1994, pp. 53-65.

${ }^{33}$ J.Z. Sawicki, op. cit., pp. 46-47.

${ }^{34}$ AAN, GUKPPiW, ref. no. 600 (68/8), 1. 153a, b.

${ }^{35}$ E. Dziębowska, J. Dargiel, Śpiewnik zastępowy, Poznań 1958, p. 89.

${ }^{36}$ AAN, GUKPPiW, ref. no. 600 (68/8), 1. 153f, g.

${ }^{37}$ Underneath the image there was a fragment of The Internationale lyrics crossed out in red; a circled arrow indicating that one of the censors signalled the misalignment of the image and the content underneath, which could result in the need to relocate the image. However, the published
} 
indicate that the fight using symbols ${ }^{38}$, which had been started before the end of Second World War, was still ongoing. Marsz Mokotowa, which had neither been questioned in the review nor removed during the primary verification, was removed from the collection. However, the fact that it was archived by the Bureau in the sample copy version could indicate that the censor had doubts about the song, which was eventually eliminated. Yet, it seems much more probable that it was removed by the publishing house (and later the decision was approved by censorship). It is possible that the removal of the song from the collection was caused not by its political meaning but musical issues. Marsz Mokotowa did not offer cheerful lyrics and an upbeat tempo, which is important in the case of scout songs.

Therefore, the published version of the songbook included only two songs from the Uprising: Palacyk Michla and Parasola piosenka szturmowa [Parasol's Assault Song] ${ }^{39}$.

\section{Prose}

A large portion of prose books published constituted a combination of fiction with recollections by their authors of actual historical events. That resulted in the creation of hybrids: novels with elements of commentary or author's observations, fictionalised memoirs, and recollections expressed in a literary image. Considering the form of the analysis and the extensive nature of the material I shall omit those works which can be classified at the borderline between belles-lettres and factual genres, and I shall focus in detail strictly on fiction.

Very few of the stories which were sent to the GUKPPiW in 1956-1958 directly raised the topic of the Warsaw Uprising. Fragments related to those events, e.g. the prayer of the hospital nurses over the fighters who fell during the fights in Warsaw in 1944 (ending in "for peace on Earth") or the explanation of the "amnesia" of the main character as a result of the events were rare and discrete instances. Those examples could be found in two stories by Pola Gojawiczyńska: Za pokój świata [For Peace On Earth] and Kapelusz [Hat $]^{40}$. However, short inclusions on the Uprising did not matter much for censorship and did not raise many

version of Śpiewnik missed the image altogether. That confirms not only that the image was inappropriate, but also how negative the attitude of censorship towards the symbol was. Vide ibidem, 1. $153 \mathrm{k}$.

${ }^{38}$ The symbol of the "anchor" was also removed from book previews. Vide ibidem, ref. no. 427 (34/6), 1. 79.

${ }^{39}$ E. Dziębowska, J. Dargiel, op. cit., p. 93.

${ }^{40}$ P. Gojawiczyńska, Opowiadania, Poznań 1956, pp. 250, 253, 260. 
doubts. Censor Trębicki only stated in his review that the topic of the story $Z a$ pokój świata is related to the period of Nazi occupation ${ }^{41}$.

On 18 February 1957 GUKPPiW received from PIW a novel by Roman Bratny ${ }^{42}$ entitled Kolumbowie rocznik 20. [Columbuses of 1920] without a specified number of $\operatorname{copies}^{43}$. The review of the second volume, the plot of which was set during the Uprising, is scanty and generalist, contained in two short sentences: "The characters from volume 1 participate in the Warsaw Uprising. The intention of placing on page 255 an ongoing evaluation of the Uprising performed by $1^{\text {st }} \mathrm{Di}$ vision propaganda specialists seems questionable" 44 . Many more of the censor's remarks were included in the discussion of the final volume, mainly because of the "allusive Soviet elements" and the consequences of Operation Tempest. Nonetheless, the entire review displays recognition of Bratny's activities: "It is certain that Roman Bratny, a Home Army officer, editor of the Pokolenie journal, has put onto its pages his passion to present the process of how the so-called Home Army complex forms $[\ldots]^{345}$. The fragment containing the negative evaluation of the Uprising fighters by the Kościuszko Radio Station which raised the censor's doubts was not removed ${ }^{46}$. Even though the novel did reveal the aggressive communist manipulation (considered by the censor as propaganda of the Polish Tadeusz Kościuszko Division), the second volume together with the other parts received a publication permit already on 30 March.

It would seem that setting the plot in the underground was riskier that choosing regular inhabitants of contemporary Warsaw as the main characters. However,

${ }^{41}$ AAN, GUKPPiW, ref. no. 424 (31/36), 1. 86.

${ }^{42}$ Bratny, being a member of the Home Army, participated in underground literary life and the secret teaching of cadets. At the age of 23 , he fought in the Uprising. He was second in command of a platoon in the Śródmieście-Południe group. He received the rank of officer and after the fall of the Uprising he was imprisoned in Nazi POW camps. In 1945, he returned to Poland. Vide A. Szałagan, Bratny Roman, in: Współcześni polscy pisarze..., vol. 1, 1994, p. 260.

${ }^{43}$ AAN, GUKPPiW, ref. no. 426 (34/3), 1. 369.

${ }^{44}$ Ibidem, 1. 370.

${ }^{45}$ Ibidem, 1. 370-371.

46 "Through the static of poor reception [of the radio - A.K.] began to peer single words: In Poznan there are still some militants of Sosnkowski's fascist gangs fighting in a few streets of Śródmieście. The city, the victim of a criminal provocation, is burning"...

- reported the speaker in a pretentious voice.

Sudden silence struck like lightning.

- This is Lublin speaking, radio station "Kościusz"...

The bottle from Zygmunt's hand went flying over the table, passing a centimetre from Jerzy's bowed head and smashed the glass of the radio scale.

- "Shut his damn mouth!" someone shouted hysterically. Jerzy cracked the switch as if locking a spare rifle.

- "Are we gonna create our platoon, Zygmunt?..." he came to him ostentatiously, with his normal determination. - "We are", he repeated as if he wanted to apologise for something". (R. Bratny, Kolumbowie rocznik 20., vol. 2: Śmierć po raz drugi [Die A Second Time], Poznań 1957, p. 255). 
the "danger" of the topic of the Uprising itself required the authorities to carefully study the future publication. Obok zaglady [Next To Extermination] by Tadeusz Łopalewski ${ }^{47}$, sent to GUKPPiW by the MON publishing house in late July 1957, was released to the censor on 1 August, and on 6 August the review was ready and on 8 August the censor's signed approval was issued: "Burczyn M. approved for print without interventions". The pace of the decision-making suggested there were no problems of the "censorship kind" with the novel. However, the review does include some anonymous statements: "A rather medium-grade novel, without any attempts at a deeper evaluation of the events, nor some kind of epic presenting the tragic heroism of the Uprising fighters. The author simply focussed on the fortunes of a single downtown tenement house [... ${ }^{348}$, to state in another location: "The atmosphere of the entire book reveals a deep recognition of the bravery and the unwavering moral strength of Home Army fighters as the main driving force of the Uprising"49. The inconsistency in the censor's approach displayed the general consent of the GUKPPiW to writing about Uprising fighters as heroes but without "excessive" glorification of the Home Army. It seems, though, that until the mid-1957, the borderline between permitted and prohibited content regarding the above issue was in flux and largely depended on the view of a given officer and his/her personal "censor parameter". A big advantage for the reviewer of the novel was the depiction of the landing of the $1^{\text {st }}$ Army of the Polish Armed Forces and the humorous description of the People's Army partisans and their participation in the "night-time libation at the peasant's place". However, the juxtaposition of the bravery of the Home Army and the heroic offensive of the Soviet offensive and the joint fight of the People's Army and Home Army within the ranks of the $1^{\text {st }}$ Army of the Polish Armed Forces were the main reasons for the positive reading of the content and identifying its optimistic meaning ${ }^{50}$.

The censor's opinion in a review of mid-1958 by J. Wielopolski regarding a novel by Ryszard Liskowacki ${ }^{51}$ entitled Po tamtej stronie życie ${ }^{52}$ [On The Other Side Of Life] was quite different. When describing a group of teenaged boys who decided to organise a division for combating the occupying forces, the author did

47 Tadeusz Łopalewski (born in 1900) was in Vilnius, which at that time already belonged to the Lithuanian Soviet Socialist Republic, when the Warsaw Uprising broke out. He fulfilled the function of literary manager of the Polish Dramatic Theatre. He was not a member of the Home Army. Vide J. Zawadzka, Łopalewski Tadeusz, in: Wspótcześni polscy pisarze..., vol. 5, 1997, p. 179.

${ }^{48}$ AAN, GUKPPiW, ref. no. 426 (34/4), 1. 633 [631].

${ }^{49}$ Ibidem, 1. 633 [632].

${ }^{50}$ Ibidem.

${ }^{51}$ Ryszard Liskowacki (born in 1932) at the age of twelve being a member of the Grey Ranks participated in the Uprising. Though young he fulfilled the function of liaison officer in Żoliborz. Vide K. Batora, Liskowacki Ryszard, in: Wspótcześni polscy pisarze..., vol. 5, 1997, p. 119.

${ }^{52}$ The novel, with a planned circulation of 5,000 copies, was sent to GUKPPiW by Lubelska Spółdzielnia Wydawnicza - Lublin. 
not specify the political affiliation of the emerging squad, which was, in principal, apolitical, and yet it caused some interpretation problems to the officer:

They [the boys - A.K.] have obviously been inspired by someone [...] the movement has been inspired by the Home Army. Those are not "Grey Ranks", though the assumptions continues to reach the reader, neither is it an "official" division of the Home Army, but the inspiration method and the utilisation of those people in action permits such a possibility. And indeed, the later fortunes of the group and the order to join the Uprising activities in particular comes from the still invisible Home Army $[\ldots]^{53}$.

The censor proceeded to enumerate the novel's advantages, i.e. "realistic recreation of the nightmare of occupation", "the hopeless situation of the youth", the presentation of the "activities of the unidentified instigator" and mainly the fact that the group "is far from any political paths" and wishes to fight while the leadership is characterised by "odd procrastination". This outlined the censorship's approval for the dichotomy: the gallant and unaware lower ranks and the politically calculating Home Army top echelon. Additionally, in the review the censor attempted to discuss the slogan "to stand with a weapon at your side". However, the censor supplemented his thoughts with a comment: "[...] it seems, though, that the author did not do it as carefully as the situation required"54. The Bureau's position regarding the slogan in 1956-1958 evolved: only Home Army leadership stood "with a weapon at their side" while regular soldiers willing to fight were curbed and stopped by the top echelon. Nonetheless, the authorities returned in the 1960 s to the promotion of the image of a passive Home Army in general ${ }^{55}$.

In line with the censorship requirements regarding "political tendencies" Liskowacki presented the outbreak of the Uprising as chaotic in the context of general confusion, which led to the death of nearly the entire group of boys. Therefore, the political reading of the novel in the discussed instance could not raise any censorship reservations.

Another important, from the perspective of the Bureau, issue was the need to depict the achievements of the People's Army in the struggle. But a lack of any content regarding the People's Army did not offer basis for halting the novel. To somewhat justify the above-mentioned "mistakes" the censor concluded:

It [the novel - A.K.] thus lacks space for an even marginal treatment of left-wing combat forces. It is a story of a group of Warsaw youths who wished to fight but did not realise why the fight takes place so much later than they would expect ${ }^{56}$.

\footnotetext{
${ }^{53}$ AAN, GUKPPiW, ref. no. 599 (68/6), 1. 3.

${ }^{54}$ Ibidem.

${ }^{55}$ Z. Romek, op. cit., p. 293.

${ }^{56}$ AAN, GUKPPiW, ref. no. 599 (68/6), 1. 3.
} 
The issue of the author's attitude towards the Soviet Army, stationed at that time near Warsaw, was neither omitted. But a lack of a reaction over his rejection of the Polish Workers' Party's (PPR) program and the criticism and ridicule of the left-wing propagator during a meeting of the underground ${ }^{57}$ indicated low interest on the part of the Bureau in the author's creating or describing the relations between individual underground fractions.

The final fragment of the review where the censor concluded: "It is indeed yet another novel about the Home Army, but considering its fundamentally different approach to the issue as well as the fact that it is Liskowacki's début, I support the permit for publication" 58 indicated that already in mid-1958 works raising the issue of the Home Army were approached reluctantly. The author knew that, hence intentional avoidance of naming the organisation. On the other hand, censors stopped focussing so much on the plot and concentrated on comparing elements of a novel with reality and the promoted assumptions of the authorities.

The group of prose works which were published upon intervention included a work by Jerzy Krzyszton ${ }^{59}$ entitled Kamienne niebo [Sky Made Of Stone]. It was the best example of a novel the plot of which was set during the Warsaw Uprising, but the story focussed on presenting the psychological aspects of the attitudes of the characters while avoiding any evaluation or specific account of the events. One departure from that was a scene in which the Uprising fighters were evaluated by their former professor ${ }^{60}$, but the fragment was eventually censored. The officer, clearly impressed by the novel, focussed in his short review only on the tragedy: "The book drips with terror, terror of death which for six days slowly closed in on those buried alive. The author fortunately spared the readers the description of the final moments of suffocating in the cellar. What there is, is enough" ${ }^{1}$. The utterly pessimistic novel, though missing any inconvenient political elements, after intervention on page $58^{62}$, was published by Iskry publishing house in the suggested number of 10,000 copies.

${ }^{57}$ R. Liskowacki, Po tamtej stronie życia, Poznań 1958, p. 70-71.

${ }^{58}$ AAN, GUKPPiW, ref. no. 599 (68/6), 1. 3.

59 Jerzy Krzyszton did not participate in the Warsaw Uprising, but his biography related to the WWII period is particularly interesting. Aged nine, in 1940, while living in Grodno, he directly experienced Stalinist repression: his father was arrested by the NKVD and he, together with his mother and brother, were deported to Kazakhstan. Two years later he managed to join Gen. Anders' army forming in the USSR and with it he evacuated to the Middle East, to Persia, India and Uganda. In 1948, he returned to Poland. Vide J. Zawadzka, Krzysztoń Jerzy, in: Współcześni polscy pisarze..., vol. 4, 1996, p. 408.

${ }^{60}$ J. Krzysztoń, Kamienne niebo, Poznań 1958, p. 58.

${ }^{61}$ AAN, GUKPPiW, ref. no. 597 (68/4), 1. 82.

${ }^{62}$ Unfortunately, no report of the preventive inspection of the novel survived and it is difficult to state what type of intervention it entailed. One might only assume on the basis of the remaining text on pages 57 and 58 that it was related to the evaluation of the Uprising fighters as national heroes. 
A novel entitled Pejzaż dwukrotny [Double Landscape] by Lesław Bartel$\mathrm{ski}^{63}$, a former officer at the Bureau of Information and Propaganda of the Home Army HQ in Częstochowa, raised many controversies. It was also an excellent example of how a group of censors with completely different views came to an agreement. Bartelski's manuscript was sent by the Czytelnik publishing house on 3 October 1958 for an application for a permit with a deadline of 10 October for 5,000 copies $^{64}$. The first extensive review by censor Rutkowski of 16 October clearly indicated that the novel could not be published. He mainly focussed on the analysis of the feelings of the characters, representatives of the Home Army lower ranks, whose actions were determined by the "underground habit", the "myth of discipline" and the "cult of loyalty" towards the Home Army leadership. The fact of Rutkowski's focussing on this psychological aspect led to the conclusion that the novel's title should be: Bohaterowie sa zmęczeni [Heroes Are Tired]. Yet he reserved his biggest accusations against the text for the final part of the review, criticising the manner in which the author handled the issue of the youth within the ranks of the Home Army. Through "original and impressive" deduction he concluded that the novel was founded on historical fatalism and indicated the need to reject the heroic creation of people who displayed patriotism and ideological focus:

Bartelski handles the problem of Home Army youth not only ahistorically, but, what is even worse, fatalistically. Thus, he offers historical fatalism which turns those patriotic and ideology-focussed people into wrecks. [...] It is unacceptable to turn those people into such pompous characters who have the right (and that is the worst thing here) not to believe in anything $[\ldots]$ and that is a political problem. [...] They [the characters - A.K.] wish to endure in Warsaw [...]. Whether they will conspire remains unknown. Whether they will start new lives also remains unknown. Such an arrangement is politically (but also historically) detrimental and untrue. It elevates the Home Army mass as spotless heroes without absolving many of them of the evil that they had surely committed. [...] I believe the book is not appropriate for publication ${ }^{65}$.

${ }^{63}$ Aged only nineteen Lesław Bartelski participated in the defence of Warsaw during the September Campaign. After the capital was captured by the Nazis, he was imprisoned. He escaped and returned to Warsaw. He was active in the creation of the underground as a member of ZWZ, later of the Home Army and he participated in the underground literary life. He took part in the Warsaw Uprising initially fighting in the Baszta Home Army regiment and then in the Headquarters of the $5^{\text {th }}$ District in Mokotów, for which he received the Cross of Valour. After the Uprising he was taken to Świdnica as a forced labourer; he soon escaped to Częstochowa where he fulfilled the function of officer at the Office of Information and Propaganda of the Home Army HQ. In the early-1945, he returned to Warsaw soon becoming a member of the Polish Writers' Union. Vide A. Szałagan, Bartelski Lesław, in: Współcześni polscy pisarze..., vol. 1, 1994, pp. 108-109.

${ }^{64}$ AAN, GUKPPiW, ref. no. 596 (68/3), 1. 277.

${ }^{65}$ AAN, GUKPPiW, ref. no. 596 (68/3), 1.290 [287-288]. 
Regardless of some of its contradictory passages, the review did present some fundamental conclusions. The accusation of its ahistorical nature indicated that, according to the authorities, the narrator should present the story in a way which would not contradict contemporary propaganda and at the same time it should remain in compliance with the pre-defined method of historical narration, it should offer an account of the past regardless of personal experiences or any ideas for making the story more attractive. The second accusation, regarding its fatalism, constituted in the eyes of the censor a confirmation of his own judgement about the optimistic Socialist realism convention applicable during the Stalinist times and still partially applicable at that time. However, the main flaw of the novel was the fact that it presented the heroism of Home Army soldiers, regardless of any division into lower ranks or top echelon.

The negative evaluation of the novel required another review by a different officer. Out of two "landscapes" (the period of the Warsaw Uprising and the following events) Podhorska selected the post-Uprising time and focussed on the participation of the main protagonist not in the fight for Warsaw but on his activities in the partisan forces. Apart from the murder of a soldier from Bering's army, the somewhat idealised figure of the main protagonist, Nurt and the artificial (i.e. differing from the actual historical facts) nature of some of the scenes, she noticed in the novel many positive elements: the objective presentation of the Home Army underground, statements about the quick reconstruction of Warsaw, the lack of political reservations and the generally good impression which the book supposedly made. The proposed interventions applied to only four pages ${ }^{66}$.

Having two contradictory reviews, it was necessary to hand the matter over to another censor who became an arbitrator issuing the final judgement ${ }^{67}$. Therefore, in his review Stępkowski focussed mainly on undermining the arguments of Rutkowski, the author of the negative review. He began with the psychological analyses of the attitudes of the characters, whose behaviour he justified with the shock caused by the failure of the Uprising, thus rejecting the claim about the "historical fatalism" stating that: "The accusations of ahistorical and fatalist nature and objective falsehood [...] are, in my opinion, exaggerated, forced and biased" ${ }^{68}$. Additionally, in the character of Bizun Strzępkowski he found a representative of Home Army top echelon and specifically defined him as a Sanation officer and a commander of the Freedom and Independence organisation, and positively evaluated Nurt's opposition to his orders. Moreover, he saw originality

${ }^{66}$ Ibidem, 1. 291 [292-293].

${ }^{67}$ In the event of a negative evaluation by the third censor and when confronted with the particularly favourable review by Podhorska, the novel could had been released to another officer for evaluation. As Kamila Budrowska stressed, in the case of controversial works the number of initial reviews could reach a dozen or even more. Vide K. Budrowska, op. cit., p. 24.

${ }^{68}$ AAN, GUKPPiW, ref. no. 596 (68/3), 1. 295. 
in the creation of the main protagonist and his fictional fortunes explained using actual events:

To demand from the author for Nurt or others like him to immediately declare on whose side they are on [...] is to hanker for literature which is derivative and formulaic. We know what happened later to those people from our own observations and the most recent history [...] most of them entered active life. So what if it is missing from the book... maybe the author will write a sequel ${ }^{69}$.

The suggestions to change the text applied to individual details on nine pages of the novel.

The third review concluded with a decision approving the book's publication upon applying a few interventions. However, for the novel to be approved for printing and editing required the decision to be made as a group and unanimously. First, through discussion, the group convinced Rutkowski to change his position, which he confirmed in writing on 30 October on one of the copies of his review $^{70}$. Then, there was a meeting of a commission composed of: Stępkowski, Światycka and Szlajfer; they decided that interventions would be applied to five pages $^{71}$. Specifically: on page $56^{72}$, the name Radkiewicz ${ }^{73}$ was removed. The goal was to avoid ridiculing not so much the person (in 1957 Radkiewicz fell into disgrace among the Party) as the institution: the Public Security Ministry at the Polish Committee of National Liberation (PKWN). On page 79 "Ukrainians" were replaced by "własowcy" 74 , which made the passage historically incorrect as no troops associated with General Andrey Vlasov participated in the Warsaw Uprising. However, the 31. Schutzmannschafts-Bataillon der SD commanded by

${ }^{69}$ Ibidem.

${ }^{70}$ Rutkowski wrote: "In relation to the review by comrade Stępkowski and the discussion on the book I agree with the comments by comrade Stępkowski - to publication of the book with minor interventions" (ibidem, 1. 297).

${ }^{71}$ Ibidem, 1. 291.

${ }^{72}$ In the initial version of the text, after the Warsaw Uprising, Andrzej, one of the characters, said to Nurt: "- And what did you do with the rifle, you blockhead? You gave it to the museum or donated it for the poor at the brother Radkiewicz' shelter?" while in the published version Andrzej said: "[...] You gave it to museum or donated it for the poor?" (L. Bartelski, Pejzaż dwukrotny, Poznań 1958, p. 58). Vide AAN, GUKPPiW, ref. no. 427 (34/5), 1. 19.

${ }^{73}$ During the Warsaw Uprising, Stanisław Radkiewicz led the Public Security Ministry at PKWN (he fulfilled the function until the end of 1944). As a Minister of Public Security (since 1954) he was responsible for organising Stalinist terror in Poland according to the Soviet formula. In 1957, he was punished for Stalinist crimes and removed from PZPR only to be reinstated three years later.

${ }^{74}$ The fragment: "The passage was risky, under machine gun fire from both sides - the Water Supply field was filled with Ukrainians of the worst kind [...]" was changed to: "[...] filled with własowcy of the worst kind" (L. Bartelski, op. cit., p. 79). Vide AAN, GUKPPiW, ref. no. 427 (34/5), 1. 20. 
Petro Dyachenko did participate in the Uprising, thus Bartelski's censored description was accurate. The goal behind that intervention was probably to emphasise that collaborationist Ukrainian units of fascist bias participated in the Uprising to avoid fostering in Poles any aversion towards the USSR. For censors the term "własowcy" was mainly a metonymic encompassing Russians, Ukrainians and Belarusians fighting with the Nazis against the USSR, however, it was also possible that the term was used at GUKPPiW in the form of a mistake ${ }^{75}$ lingering until the present day ${ }^{76}$.

Deeper interventions were made on page 102 where a fragment on the arrest of Gen. Leopold Okulicki, the last commander of the Home Army, was removed and new text was added. In that case, the censors intervention was conducted quite ingeniously: by changing a few words the censor gave the entire fragment a new logical meaning (a blow for the characters was not the arrest of Okulicki anymore, but the loss of a radio station $)^{77}$. A certain blurring of the facts was introduced in another location. The deletion by censors of the "reactionary dwarf" caption underneath a poster made the fragment quite enigmatic; after the intervention the fragment could be interpreted in various ways, even contrary to what GUKPPiW had intended ${ }^{78}$. The goal of the above-mentioned modifications was

75 Jerzy Kirchmayer, general and historian, in his 1959 study, which also passed through GUKPPiW at the end of 1958, claimed that in Warsaw there fought the RONA Brigade (known for its particular cruelty towards the civilian population) while Vlasov was organising ROA. Therefore, the complete differentiation between the two units was visible and it was not changed by censorship. However, while writing his review one of the GUKPPiW officers considered as an obvious fact that "Vlasov's troops" operated during the Uprising and did not see a difference between the fact of organising the group and its participation in the fights. Vide J. Kirchmayer, Powstanie Warszawskie, Poznań 1959, p. 260, ref. 1; AAN, GUKPPiW, ref. no. 480 (38/2), 1. 38.

${ }^{76}$ Gdyby Polacy wygrali w Warszawie [Had Poles won in Warsaw]... [an interview by Bartosz T. Wieliński with Dr. Jochan Böhler], Ale historia, issue 176 ("Gazeta Wyborcza" supplement), 30 Jul 2012, p. 10; http://www.archiwum.wyborcza.pl/Archiwum/1,0,7628093,20120730RPTAH,Gdyby_Polacy_wygrali_w_Warszawie,zwykly.html [accessed on: 1.03.2014].

${ }^{77}$ The original text read: "You, dear cadet, must understand, how stations are hard to come by these days. How they are following hard on our heels from every side. You must know that Gen. Niedźwiadek was arrested two months ago in Pruszków? - I heard. - It was widely discussed. But why am I mentioning it, dear cadet. Those kind of blows strengthen our internal discipline. So I cannot just forget about the case of the radio station and its mysterious disappearance [...]" while after the intervention: "You, dear cadet, must understand, how stations are hard to come by these days. They are following hard on our heels from every side, we are losing people. - I understand. - I'm mentioning these matters, dear cadet, as those kind of blows strengthen our internal discipline and force us to work even harder. So I cannot just forget about the case of the radio station [...]" (L. Bartelski, op. cit., p. 102). Vide AAN, GUKPPiW, ref. no. 427 (34/5), 1. 21.

78 The meaning of the fragment: "[...] Irena thought she knew one of them [the youths - A.K.], the slender handsome dark-haired man. When passing her, they stopped and the handsome one looked insolently at her. - "Face of nothing!" laughed his companion. They came closer, selfassured, eyes fixed on Irena. When she turned back following their reaction she saw a poster. It was torn, faded, nearly completely indistinct. She could still make out a part of the text: ... REAC- 
to avoid any possible associations with the repressive communist policy against the Home Army.

One of the main points during the preventive inspection was the author's presentation of the behaviour of the Red Army stationed a few dozen kilometres from the city during the heat of the Warsaw Uprising. Any statement that might have indicated that the Soviet leadership intentionally held the front underwent particularly careful analysis. The preventive inspection report indicates that for one of the censors even the sentence: "[Nurt - A.K.] was there once, he made his way with the boys to the Vistula as a cover unit - as the Home Army units from Rembertów, Praga, Anin fell back, waiting there for a contact with the Soviet Army"79, though included in the published text, did raise considerable doubts. But the short fragment included at the beginning of the novel regarding the fighting on the outskirts of Warsaw was a narrative device generally accepted by the censors. That logically justified the lack of Soviet support as it was impossible considering the heavy fighting on the extensive front. The proposed text modifications presented above (on pages 56, 79, 192, 194, and 204) were sent to the publishing house where Kopińska, chief editor of Czytelnik, was supposed to undertake negotiations with Bartelski. Moreover, the official note stated that the ending of the novel should also be altered:

I also indicated that the present handling of the book's conclusion on page 235 could be understood completely differently as the bureau cannot intervene here; I asked comrade Kopińska to request the publishing house to re-consider the text on this page. I was assured that she will do so. Answer received ${ }^{80}$.

On 7 November, nearly a month after the deadline specified by Czytelnik, GUKPPiW issued a print permit upon introduction of the interventions ${ }^{81}$. The publishing house complied with the obligatory changes on five pages, but it did not introduce the optional re-editing of the ending.

TIONARY DWARF. The young men left exchanging ironic grins. They clicked their heels like professional army men. They returned once more and the handsome dark-haired one said loudly while looking at the poster: - "Face of nothing!" [...]" (L. Bartelski, op. cit., p. 194 - underscore A.K.), after the sentence in bold was removed and the third after it was left, became even more mysterious. Vide AAN, GUKPPiW, ref. no. 427 (34/5), 1. 22. Soon after Soviet troops entered Poznan there began to appear posters with the representatives of the new authorities (e.g. Michał Rola-Żymierski or Wanda Wasilewska) so the intervention made the interpretation unclear.

${ }^{79}$ Ibidem, 1. 20.

${ }^{80}$ Ibidem, ref. no. 596 (68/3), 1. 291.

${ }^{81}$ Ibidem, 1. 277-278. 
The "Summary of interventions" within the period of 1 July 1957 - 15 June 1958 and the 1958 "List of items halted by censorship" indicate that within that period no poetry collection which directly raised the topic of the Warsaw Uprising was halted. Thus, within the specified period, the method of censoring collections of poems regarding the fighting in Warsaw was no different from the general principle of censorship ${ }^{82}$. Compositions which contained unwelcome content were simply eliminated from the collections and the permit applied to the remaining ones. One interesting case was the attempt to change the title of a poem by Ficowski, which eventually proved futile.

In 1956-1958, censorship did not particularly focus on "tracing" in poetry elements related to the Uprising which offered ambiguous interpretations. Poems with extensive metaphors based on political allusions were consciously or subconsciously filtered through the control bureau's requirements. Poetry referring to the fighting, the tragic image of the Uprising or the memory of the fallen was also accepted by censorship. Furthermore, the fact of a previous publication of a work in literary journals, i.e. the fact that it had previously been approved, could, depending on the situation, serve as an argument for publishing the entire collection (mainly in 1956) or ignored (since mid-1957). It seems it was associated with the bureau's conviction of poetry's elitist nature and its minor social influence.

Novels, on the other hand, were subjected to a more complex censorship process which indicated the existence of various degrees of intervention. They could be divided into two main groups: novels published without any interventions (not raising any political issues or free of any evaluation of the Uprising and focussing on social or psychological issues; e.g. Obok zagłady by Łopalewski) and texts in which the authors attempted to handle the issue in a generalist manner (e.g. Bartelski in Pejzaż dwukrotny). The third group (halted novels) remained "empty", but a significant indication are in archival sources from mid-1958 referring to factual genres. Reviews included important traces indicating that poetry and prose works with extensive stories were disowned and the preferred type included texts describing in a "faithful" or "scientific" manner the past events without the detrimental, in the view of censorship, "glorification of the Home Army". It seems that the topic of the Warsaw Uprising, which constituted a part of the so-called Home Army problem area, started to be considered unwelcome ${ }^{83}$ in mid-1958 at the latest, which was immediately reflected in GUKPPiW decisions.

As the above editorial stories indicate, censors did not acknowledge the existence of literary fiction in their interpretations or considered it to a minimal and minor extent, every time referring to the "historical" image of the past created by the communist propaganda. Whenever faced with ambiguity in setting the time, defining a given organisation or individual characters they always referred to the reality: the

${ }^{82}$ K. Budrowska, op. cit., p. 64.

${ }^{83}$ AAN, GUKPPiW, ref. no. 611 (68/21), 1. 2, 3. 
historical context and the political meaning. The goal was to assess whether a text adhered on the whole to the pre-established "objective truth". Fictitious characters were analysed by censors as representatives of a specific social group (organisation) whose features where supposed to present certain established models.

Additionally, the reviews (regardless of many internal contradictions) offered a specific method of reading novels which raised the topic of the Warsaw Uprising. They included certain fixed control elements, i.e. reference between the story and the reality, the censor finding positive aspects of the work, outlining political problems (this offered greater discrepancy: the sense of the Uprising, "standing with a weapon by one's side"), the outbreak of fighting, the attitude towards other nationalities (hatred towards the Germans and the so-called "własowcy"), the method of presenting soldiers with a division into lower ranks and top echelon, the significance of their role and the political superficiality, the definition of the author's attitude towards the People's Army, the Polish First Army and the Soviet Army (the issue of passiveness during the Uprising), whether the publication was the author's début and the general meaning of the book. The presence of the above-mentioned issues in reviews proves that censors possessed detailed guidelines regarding the interpretation of items related not only to the Home Army problem area but also to the Warsaw Uprising. The reviews also displayed a specific perspective, sometimes artificial, for the reading of novels as a juxtaposition of regular Home Army soldiers with the leadership or the Uprising fighters (as a uniform group) with civilians not participating in the fighting. Such a device was particularly important for approaching the issue of "standing with the weapon by one's side", which was only to apply to the top echelon of the Home Army, the London government and the Government Delegation for Poland. If a future publication did not meet this criterion, the censors would "let it slide" and issue a publication permit and at the same time would ostentatiously raise an alarm and emphasise the "flaw" of the novel.

Critical reviews did not affect the fact of granting a publication permit, even without any corrections (as in the case of the novel by R. Liskowacki entitled $P o$ tamtej stronie życia). In those conditions, not only texts which handled the topic of the Warsaw Uprising superficially focussing on the psychology, the experiences of regular inhabitants had a high chance of being published in an almost unchanged version, but also novels and poems which referred to political problems, preferably not in a too pungent manner. Nonetheless, it was unacceptable to recall the slogans or the methods used by the propaganda during the Uprising: the slogan "Home Army, the disgusting reactionary dwarf" was removed from texts of all types. The situation was different in the case of the control of press where infrequent instances when the slogan was tolerated did occur ${ }^{84}$.

${ }^{84}$ Cf. C. Kałkusiński, ***, “Życie Literackie” 17 Jun 1956, issue 25 (230) p. 11; J. Ficowski. Plwocina, “Życie Literackie” 24 Feb 1957, issue 8 (266), p. 5. 
Any negative statement about the Soviet Army, let alone its passiveness during the Warsaw Uprising, was unconditionally removed. The same applied to national issues: the presentation of the Germans as dehumanised oppressors was considered by censorship as an advantage of a work while if a text included passages referring to Ukrainians fighting on Wehrmacht's side, they would always be replaced with the still non-existent "własowcy" term.

Finally, authors were among the non-literary factors which could ensure a positive disposition of censorship towards a given text. Those making their début, publishing their works in state publishing houses (MON publishing house in particular) and most of all members of the Home Army were allowed to do more than others. A publication which described the Warsaw Uprising in line with GUKPPiW guidelines written by an actual witness to the events was an indirect confirmation of the communist "objective truth" about the Uprising.

The years 1956-1958 were clearly a period of liberalisation. After almost a decade of non-existence the topic of the Warsaw Uprising re-appeared in literature. Since 1956 the Bureau received poems which were an instant response to the changes in the country, though they were not free of the evident self-censorship on the part of their authors. Longer prose pieces appeared in 1957, a year which was special because of the exceptionally lax censors' approach. But already in 1958 the level of criticism towards texts raising the topic of the Home Army intensified, which in turn resulted in a decrease of the presence of the topic in belles-lettres.

\section{Bibliography}

AAN, GUKPPiW, ref. no. 426 (34/4), 1. 633 [631].

AAN, GUKPPiW, ref. no. 426 (34/2), 1. 20.

AAN, GUKPPiW, ref. no. 426 (34/2), 1. 36.

AAN, GUKPPiW, ref. no. 424 (31/6), 1. 83.

AAN, GUKPPiW, ref. no. 424 (31/36), 1. 82.

AAN, GUKPPiW, ref. no. 424 (31/36), 1. 86.

AAN, GUKPPiW, ref. no. 426 (34/3), 1. 369.

AAN, GUKPPiW, ref. no. 427 (34/5), 1. 19.

AAN, GUKPPiW, ref. no. 427 (34/5), 1. 20.

AAN, GUKPPiW, ref. no. 427 (34/5), 1. 21.

AAN, GUKPPiW, ref. no. 427 (34/5), 1. 22.

AAN, GUKPPiW, ref. no. 480 (38/2), 1. 38.

AAN, GUKPPiW, ref. no. 497 (39/3), 1. 52.

AAN, GUKPPiW, ref. no. 596 (68/3), 1. 277.

AAN, GUKPPiW, ref. no. 596 (68/3), 1. 290 [287-288].

AAN, GUKPPiW, ref. no. 596 (68/3), 1. 295.

AAN, GUKPPiW, ref. no. 597 (68/4), 1. 82.

AAN, GUKPPiW, ref. no. 599 (68/6), 1. 3. 
AAN, GUKPPiW, ref. no. 599 (68/6), 1. 3.

AAN, GUKPPiW, ref. no. 599 (68/6), 1. 3.

AAN, GUKPPiW, ref. no. 600 (68/8), 1. 153f, g.

AAN, GUKPPiW, ref. no. 600 (68/8), 1. 153a, b.

AAN, GUKPPiW, ref. no. 611 (68/21), 1. $2,3$.

Ambroziewicz Jerzy, Namiotkiewicz Walery, Olszewski Jan, Na spotkanie ludziom z AK, "Po prostu" 1956 , issue 11, p. 7.

Bartelski Lesław, Pejzaż dwukrotny, Poznań 1958

Bratny Roman, Kolumbowie rocznik 20., vol. 2: Śmierć po raz drugi [Die A Second Time], Wydawnictwo Poznańskie, Poznań 1957.

Budrowska Kamila, Literatura i pisarze wobec cenzury PRL 1948-1958, Wydawnictwo Uniwersytetu w Białymstoku, Białystok 2009.

Ficowski Jerzy, Plwocina, "Życie Literackie” 1957, issue 8 (24 Feb).

Fijałkowska Barbara, Polityka i twórcy 1948-1959, PWN, Warsaw 1985.

Galant Jan, Odmiany wolności. Publicystyka, krytyka i literatura polskiego Października, Wydawnictwo UAM, Poznań 2010.

Gdyby Polacy wygrali w Warszawie [Had Poles won in Warsaw]... [an interview by Bartosz

T. Wieliński with Dr. Jochan Böhler], Ale historia, issue 176 (“Gazeta Wyborcza” supplement), $30 \mathrm{Jul}$ 2012, p. 10; http://www.archiwum.wyborcza.pl/Archiwum/1,0,7628093,20120730RP-

TAH,Gdyby_Polacy_wygrali_w_Warszawie,zwykly.html [accessed on: 1.03.2014].

Głowiński Michał, Rytuat i demagogia. Trzynaście szkiców o sztuce zdegradowanej, Open, Poznań 1992.

Mielczarek Tomasz, Pisarze w PRL "pieszczochy władzy" czy ofiary systemu, in: Niewygodne dla władzy. Ograniczenie wolności stowa na ziemiach polskich w XIX i XX wieku, D. Degen, J. Gzella (eds.), Wydawnictwo Naukowe UMK, Toruń 2010, pp. 213-231.

Polska 1956: próba nowego spojrzenia. materiały sesji naukowej zorganizowanej przez Instytut Historii PAN, Polskie Towarzystwo Historyczne i Instytut Studiów Politycznych PAN w Warszawie w dn. 21-22 października 1996 r., K. Kersten (ed.), Series: "Polska 1944/45-1989. Studia i materiały", vol. 3, IH PAN, PTH, ISP PAN, Poznań 1997.

Romek Zbigniew, Cenzura a nauka historyczna w Polsce, 1944-1970, Neriton, Warsaw 2010.

Sawicki Jacek Zygmunt, Bitwa o prawdę. Historia zmagań o pamięć Powstania Warszawskiego. 1944-1989, DiG, Poznań 2005.

Słownik realizmu socjalistycznego, Z. Łapiński, W. Tomasik (eds.), Universitas, Cracow 2004.

Wyka Kazimierz, Składniki świetlanej struny, “Życie Literackie” 14 Oct 1956, issue 247.

Wspótcześni polscy pisarze i badacze literatury. Słownik biobibliograficzny, J. Czachowska, A. Szałagan (eds.), Wydawnictwa Szkolne i Pedagogiczne, Warsaw 1994. 
Agnieszka Kloc

\section{Censorship Towards the Subject of the Warsaw Uprising in Belles-Lettres in $1956-1958$}

\section{(Summary)}

Right from the beginning, the subject of the Warsaw Uprising was often manipulated or even entirely erased from public discourse under the Stalinist regime. It was only after the liberalization of culture and the easing of censorship-related repressions that the said topic returned in literature. The paper focuses on the censorship bureau's approach to the image of the Uprising presented by writers. Moreover, it attempts to specify - on the basis of specific examples - the kind of content that was accepted, rejected or amended. The juxtaposition of censors' documents and the content of the published works allows for the examination of the depth of censors' interventions and their methods of manipulating historical facts. Those areas of special interest include: presentation of the division among the insurgents who were supposed to belong either to the brave ordinary soldiers or the passive leadership, as well as the attitude towards the People's Army, the First Polish Army, the Home Army or the Red Army, with special regard for its passiveness during the Uprising.

Keywords: Warsaw Uprising, censorship in Polish People's Republic 